\title{
Comparative study on the semen quality characteristics of parthenotes and parent toms reared in Nsukka
}

Udeh, F. U., Ohagenyi, I. J., Ikeh, N. E., Onodugo, M. O., Udeh, V. C. and Ezea, J. E. Department of Animal Science, University of Nigeria, Nsukka

Correspondence author: fredrickudeh11@gmail.com; +2348062457193

\begin{abstract}
The study was conducted to evaluate the semen quality characteristics of turkey parthenotes and parent toms. A total of twenty-four turkeys were used for the study. These comprised of twelve parthenotes toms and twelve parent toms. Parthenotes are male turkeys produced through parthenogenesis. The toms were subjected to abdominal massage techniques for semen collection. Semen collection was done twice per week and analyzed for volume, motility, sperm concentration, like sperm, abnormal sperm, normal sperm, dead sperm, total sperm/ejaculates and total motile sperm cells. The results showed that there were significant differences $(p<0.05)$ in semen volume, sperm concentration, normal sperm cell, abnormal sperm and total motile sperm with mean values being $0.35 \mathrm{~mL}, 1.74 \times 10^{9} / \mathrm{mL}, 97.80 \%, 2.20 \%$, $1.68 \times 10^{12}$ and $0.41 \mathrm{ml}, 1.50 \times 10^{9} / \mathrm{mL}, 94.00 \%, 6.00 \%$ and $1.42 \times 10^{12}$, respectively for both parthenotes and parent toms. However, semen parameters such as motility, live sperm cell, dead sperm cell and total sperm/ejaculate showed no significant difference $(p>0.05)$ with values of $96.7 \%, 97.7 \%, 2.30 \%$ and $6.07 \times 10^{9}$ for parthenotes toms and $93.20 \%, 98.50 \%$, $1.50 \%$ and $6.23 \times 10^{9}$ for parent toms. It was observed from the results that turkey parthenotes possess good quality semen characteristic and therefore, recommended for use in poultry industry for turkey production.
\end{abstract}

Keywords: Turkeys, semen quality, parthenotes and parent toms

\section{Introduction}

Parthenogenesis is a natural form of asexual reproduction in which growth and development of embryos occur without fertilization (Walker, 2010). In animals, parthenogenesis means development of an embryo from an unfertilized egg cell and is a component process of apomixis (Walker, 2010). Gynogenesis and pseudogamy are closely related phenomena in which a sperm or pollen triggers the development of the egg cell into an embryo but makes no genetic contribution to the embryo (Savage, 2005). The rest of the cytology and genetics of these phenomena are mostly identical to that of parthenogenesis. The term is sometimes used inaccurately to describe reproduction modes in hermaphroditic species that can reproduce by themselves because they contain reproductive organs of both sexes in a single individual's body
(Savage, 2005). However, these species still use fertilization. Parthenogenesis occurs naturally in many plants, some invertebrate animal species (including nematodes, water fleas, some scorpions, aphids, some bees, some Phasmida and parasitic wasps) and a few vertebrates (such as some fish, amphibians, reptiles and very rarely birds). Among the vertebrates, strict parthenogenesis is only known to occur in lizards, snakes, birds and sharks, with fish, amphibians and reptiles exhibiting various forms of gynogenesis (a phenomena in which a sperm triggers the development of the egg cell into an embryo but make no genetic contribution to the embryo (Walker, 2010; Savage, 2005). Savage (2005) also noted that this type of reproduction has been induced artificially in a few species including fish and amphibians.

Parthenotes are male turkeys produced 


\section{Comparative study on the semen quality characteristics of parthenotes and parent toms}

through parthenogenesis (without mating and fertilization) whereas parent toms are male turkeys produced through mating and fertilization. This is explained by the fact that in birds, the sex of the embryo is determined by the egg, not the sperm (as it is in humans and most other mammals). Avian sex differentiation is not determined by XY chromosomes like it is in humans and most mammals (or even the XO system used by some insects). In those systems, the sex is determined by what the male contributes to the offspring. By contrast, birds have a ZW system of sex determination (shared with butterflies, moths, fish and reptiles). The males have homozygous $\mathrm{ZZ}$ chromosome while the females have heterozygous ZW chromosome. In that system, sex is determined by the female within her ova, and the sex of offspring is not affected at all by the sperm which the male contributes.

The incidences of parthenogenesis in turkey have contributed to the evident improvement in the growth of turkey industry. Walker (2010) defined parthenogenesis as the natural form of asexual reproduction in which growth and development of embryos occur without fertilization. McDaniel (2007) reported that some female organisms are capable of producing an ovum which develops into a new individual without being fertilized by a male gamete. In this case, the mother only contributes her genetic material to the offspring. Natural parthenogenesis is frequently observed in rotifers, insects, mollusk, crustaceans and flat worms, though; this method of reproduction is much less common among vertebrates (McDaniel, 2007). However, a few species of fish, amphibians and reptiles are known to reproduce via parthenogenesis. Turkey is very unusual being a bird which can reproduce through this means (McDaniel, 2007). Parthenogenesis occurs in turkeys through the doubling of haploid cells.
Biologists have discovered that the rate at which this occurs can be increased by selective breeding (McDaniel, 2007). Poults produced through parthenogenesis are capable of growing into healthy viable toms indistinguishable from toms with more traditional parentage. Parthenogenesis was first discovered by Olsen and Marsden (1953). They found that $14 \%$ of the unfertilized eggs laid by BeltsVille small white (BSW) turkeys developed parthenogenically. Thus, this study was conducted to see if the Nigerian indigenous turkeys can exhibit the same quality traits exhibited by BSW turkeys which will as well help to bridge the gap of animal protein shortage in Nigeria and boost the growth of turkey industry.

\section{Materials and methods Studylocation}

This experiment was carried out in the Poultry Unit of the Department of Animal Science Teaching and research farm, University of Nigeria, Nsukka. Nsukka is in Enugu state, Nigeria and lies between latitude $06^{\circ} 52^{\prime} 24^{\prime \prime} \mathrm{N}$, Longitude $07^{\circ} 39^{\prime} 23^{\prime \prime}$ $\mathrm{E}$ and 550 meter elevation above the sea level. Nsukka covered land Area of $17.52 \mathrm{sq}$ mi $\left(45.38 \mathrm{~km}^{2}\right)$ with a population of 309,633 people (Federal Republic of Nigeria Official Gazette, 2007). The climate in this area is humid tropical with average annual rainfall of $1680-1700 \mathrm{~mm}$. the mean ambient temperature is $26.6{ }^{\circ} \mathrm{C}$ (Breinholt et al., 1981).

\section{Experimental birds and management}

A total of 24 mature local turkeys were used for the experiment, these comprised of twelve parthenotes and twelve parent toms. The two groups were housed separately. The toms were trained for semen ejaculation over a period of four weeks. The toms were subjected to abdominal massage techniques for semen collection. Semen collection was done twice per week and 
evaluated for semen quality characteristics. Parameters considered were semen volume, percentage sperm motility, sperm concentration, percentage abnormal and normal sperm, percentage live sperm and dead sperm, total sperm/ejaculates and total motile sperm cells. The birds were given feed and water ad libitum. They were treated against external parasites such as fowl lice using Rambo (Insect powder) with permethin $0.60 \%$ as active ingredient. The birds were also dewormed and administered with multi-vitamin injections and antibiotic to boost their immunity.

\section{Experimental design and statistical analysis}

This experiment was carried out using $\mathrm{T}$. test and the model is as shown below.

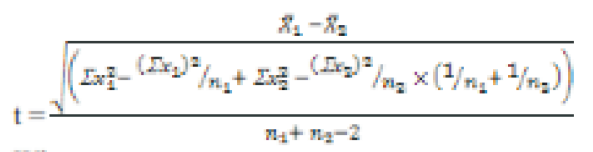

Where;

$\Sigma=$ summation

$\bar{X}_{1}=$ mean of the $\mathrm{X}_{1}$

$\bar{X}_{2}=$ mean of the $X_{2}$

$\Sigma x_{1}^{2}=$ the sum of scores in group one then squared

$\Sigma(x)=$ sum of scores in group I

$\mathrm{n}_{1}=$ the number of scores in group one only

$\Sigma x_{2}^{2}=$ sum of all the scores in group II then squared

$\Sigma\left(X_{2}\right)=$ sum of scores in group II

$\mathrm{n}_{2}=$ the number of scores in group II

\section{Results and discussion}

The mean and probability level of semen quality characteristics of ejaculate from parthenotes and parent toms were presented in Table 2. The results indicated that there were significant $(p<0.05)$ differences in semen volume, semen concentration, normal sperm cells, abnormal sperm cells and total motile sperm cells. However, parameters such as the percentage motility, live sperm cells, dead sperm cells and total sperm in ejaculates showed no significant difference $(\mathrm{p}>0.05)$.

The semen volumes obtained in this study $(0.35$ and $0.41 \mathrm{~mL})$ for both parthenotes and parent toms, respectively were significantly $(p<0.05)$ higher than the result of Zaharaddeen et al. (2005) who reported an average volume of 0.17 to $0.2 \mathrm{~mL}$ in Bauchi State. It was also, higher than values $(0.17$, 0.24 and $0.27 \mathrm{~mL}$ ) obtained by Muhammad (2015), who subjected the indigenous Nigerian turkey toms to varying levels of protein diets $(12,16$ and $20 \% \mathrm{CP})$, respectively and Yahaya et al. (2013), who obtained volumes ranging from 0.18 to $0.25 \mathrm{~mL}$ from local turkeys in Sokoto. In similar vein, the result disagreed with those of Noirault and Brillard (1999) on progressive decrease in semen volume with increasing frequency of semen collection.

Table 2: Th e mean and probability level of semen quality characteristics of ejaculate from parthenotes toms and their parent toms

\begin{tabular}{|c|c|c|c|c|c|c|c|c|c|}
\hline Parameters & $\begin{array}{l}\text { Semen } \\
\text { Volume } \\
(\mathrm{ml})\end{array}$ & $\begin{array}{l}\text { Semen } \\
\text { Motility } \\
(\%)\end{array}$ & $\begin{array}{l}\text { Sperm } \\
\text { Conc. } \\
\text { (x10 } / \mathrm{ml})\end{array}$ & $\begin{array}{l}\text { Live } \\
\text { sperm } \\
\text { cells } \\
(\%)\end{array}$ & $\begin{array}{l}\text { Dead } \\
\text { sperm } \\
\text { cells } \\
(\%)\end{array}$ & $\begin{array}{l}\text { Normal } \\
\text { sperm } \\
\text { cells (\%) }\end{array}$ & $\begin{array}{l}\text { Abnormal } \\
\text { sperm cells } \\
(\%)\end{array}$ & $\begin{array}{l}\text { Tot. } \\
\text { sperm/ } \\
\text { eja. } \\
\left(x 10^{9}\right)\end{array}$ & $\begin{array}{l}\text { Tot. motile } \\
\text { sperm cells } \\
\left(\times 10^{12}\right)\end{array}$ \\
\hline $\begin{array}{l}\text { Parthenotes } \\
\text { Toms (PN) }\end{array}$ & $0.35^{*}$ & $96.70^{\mathrm{NS}}$ & $1.74 * *$ & $97.70^{\mathrm{NS}}$ & $2.30^{\mathrm{NS}}$ & $97.80 * *$ & $2.20 * *$ & $6.07^{\mathrm{NS}}$ & $1.68 * *$ \\
\hline $\begin{array}{l}\text { Probability } \\
\text { level }\end{array}$ & 0.049 & 0.20 & 0.004 & 0.40 & 0.40 & 0.014 & 0.014 & 0.769 & 0.003 \\
\hline $\begin{array}{l}\text { Parent toms } \\
(\mathrm{PA})\end{array}$ & $0.41^{*}$ & $93.20^{\mathrm{NS}}$ & $1.50 * *$ & $98.50^{\mathrm{NS}}$ & $1.50^{\mathrm{NS}}$ & $94.00 * *$ & $6.00 * *$ & $6.23^{\mathrm{NS}}$ & $1.42^{* *}$ \\
\hline $\begin{array}{l}\text { Probability } \\
\text { level }\end{array}$ & 0.049 & 0.202 & 0.004 & 0.402 & 0.42 & 0.016 & 0.016 & 0.769 & 0.003 \\
\hline
\end{tabular}




\section{Comparative study on the semen quality characteristics of parthenotes and parent toms}

The higher mean value obtained could be attributed to differences in genotypes and system of management. However, the result is within the normal range of volume 0.35 $0.40 \mathrm{~mL}$ as documented by Christensen (2005). The sperm motility had no significant difference $(\mathrm{p}>0.05)$ and were $96.70 \%$ and $93.20 \%$ for both parthenotes and parent toms, respectively. These values were higher than the highest values of $84.25 \pm 2.23$ and $83.47 \pm 2.30 \%$ recorded by Zaharadeen et al. (2005) in local and exotic turkey, respectively. Holsberger et al. (1998) reported a mean motility value of $90.8 \pm 1.3 \%$ for high mobility phenotype exotic turkey. Muhammad (2015) reported lower values ranging from $73.01 \%$ to $80.00 \%$ for mass motility in indigenous turkeys which showed significant differences among the varying dietary treatments. The motility values obtained in the present study agreed with those of Onyimonyi et al. (2013) who ejaculated local toms twice, thrice per week and reported no significant effect in motility of semen ejaculates. The sperm concentration was highly significant $(\mathrm{p}<0.05)$ among the two groups of toms, values being 1.74 and $1.50 \times 10^{9} / \mathrm{ml}$ for parthenotes and parent toms. These values were lower than average of $2.81 \pm 74.93 \mathrm{x}$ $10^{9} 1 / \mathrm{ml}$ reported by Zaharaddeen et al. (2005). . The results were also, much lower than the values reported by Yahaya et al. (2013) and Muhammad (2015). The sperm concentration values obtained in this study were however in agreement with those of Zaharaddeen et al. (2005) who reported that sperm concentration decreased with increasing frequency of collection and also with those of Onyimonyi et al. (2013) who reported significant difference in semen concentration ejaculate in exotic breeds subjected to once biweekly semen collection. The lower values obtained in this work could be attributed to the percentage crude protein of feed given to the animals. This is because quality feeds improves semen quality positively Muhammad (2015). The percentage live sperm cells, obtained in this study $(97.90 \%$ and $98.50 \%)$ for parthenotes and parents toms, respectively, were not significantly $(\mathrm{P}>0.05)$ different. The values were higher than results findings of Yahaya et al. (2013) and Muhammad (2015). However, the result agreed with Ngu et al. (2013) on nonsignificant difference in live sperm cells in the semen of two breeds of turkey in Bauchi State.

In the normal sperm cells, the percent morphologically intact sperm cells recorded in this study were within the acceptable range of $80-100 \%$ reported by Bearden et al. (2004) while percentage abnormal sperm cells recorded in this study were below $20 \%$ those reported by the same author as base line value beyond which fertility may be impaired. This result, however showed that high fertility could be achieved with semen from both parthenotes and parent toms. This is because increase in sperm abnormalities may reduce fertility level among breeder flock. Abnormality of $6 \%$ was obtained in parent toms when compared to that of parthenotes toms with $2.20 \%$ and were significantly different $(\mathrm{p}<0.05)$. However, the values obtained for abnormal sperm in this study were consistent with those of Zaharaddeen et al. (2005) the author reported abnormalities of $11.50 \pm 1.56 \%, 14.33 \pm 1.56 \%$ and $11.42 \pm$ $1.10 \%$ in white Nicholas and $12.58 \pm$ $1.10 \%, 10.67 \pm 1.10 \%$ and $13.92 \pm 1.10 \%$ in local toms respectively. Total sperm ejaculates were not significant $(\mathrm{p}>0.05)$. It was observed that parent toms had the highest total sperm/ejaculates when compared to that of parthenotes toms $\left(6.23 \times 10^{9}\right.$ and $6.07 \times 10^{9}$, respectively). Korlowska et al. (2005) reported $4.16 \pm$ $0.38 \times 10^{9}, 3.10 \pm 0.58 \times 10^{9}$ and $3.02 \pm 0.49 \times$ 
$10^{9}$ for BIG-6, Hybrid large white and white Nicholas toms, respectively. The values obtained in this study were however higher than those reported by these authors. The reason for this could be attributed to the individual variability in sperm production rate (Thatohatsi, 2009). The total motile sperm cell was found to be significantly $(\mathrm{p}<0.05)$ higher for parthenotes toms $(1.68$ $\mathrm{x} 10^{12}$ ) than $1.42 \times 10^{12}$ for parent toms. This is an index of fertility. It suggests further that there is genotype variation within the local breeds that can be improved. The reason for high values of total motile sperm cells in this study could be attributed to individual genotypic difference and variability in sperm production rate (Thatohatsi, 2009).

\section{Conclusion}

High fertility could be achieved with both parthenotes and parent toms when used in artificial insemination since high percentage motility and sperm concentration were obtained. It could be concluded that turkey parthenotes possess good quality semen characteristic and therefore, recommended for use in poultry industry for turkey production.

\section{References}

Bearden, J. J., Fuquay, J. W. and Willard, S. T. 2004. Applied Animal reproduction $\left(6^{\text {th }}\right.$ edn $)$ Mississippi State University. Pp. 183-196.

Breinholt, K. A. L., Gowen, F. A. and Nwosu, C. C. 1981. Influence of environmental and animal factors on day and night grazing activity of imported Holstein-Friesian cow in the humid lowland tropics of Nigeria. Tropical Animal Production 6 (4): 300 $-307$.

Christensen, V. L. 2005. Artificial Insemination (poultry). In: the merck veterinary manual $\left(10^{\text {th }}\right.$ edition $)$ USA.
Pp. 1971.

Federal Republic of Nigeria Official Gazette 2007. Legal notice on publication of the detail of the breakdown of the National and State Provisional Totals 2006 Census". Retrieved 2010-07-01.

Holsberger, D. R., Donoghue, A. M. and Froman, D. P. 1998. Assessment of Ejaculate Quality and Sperm Characteristics in Turkeys: Sperm Mobility Phenotype is Independent of Time. Poultry Science 77(11): 17111717. DOI: $10.1093 / \mathrm{ps} / 77.11 .1711$.

Korlowska, M. J., Glogowski, G. J., Dietrich, K., Kozlowski, A., Faruga, J., Jankowski, and A. Gereszko, 2005. Biochemical characteristics and sperm production of turkey semen in relation to strain and age of the males. Poult. Sci. 84:1763-1768.

Mc Daniel, C. D. 2007. Pathenogenesis. "Embryoni development in unfertilized eggs may impact normal fertilization and embroyonic mordality. Poultry Science vol. 7 issue 1. Pulished in MSU poultry Dep spring Newsletter.

Muhammad, S. Y. 2015. Semen Quality and Fertilizing ability of Indigenous Nigerian Turkey Toms (Meleagris Gallopavo) Fed Varying Levels of Protein Diets. Project submitted to the Department of Theriogenology and Production, Faculty of Veterinary Medicine Ahmadu Bello University, Zaria, Nigeria.

Ngu, G. T., Etchu, K. A., Butswat, S. R. and Woogeng, I. N. 2013. Semen and microbial characteristics of two breeds of turkey in an arid tropical environment of Bauchi State, Nigeria. Academic Journals. 8 (21). Pp. 21742182.

Olsen, M. W. and Marsden, S. J. 1953. Embryonic Development in Turkey Eggs Laid 60-224 Days Following 
Removal of Males. Proceedings of The Society for Experimental Biology and Medicine 82(4):638-641. DOI: 10.3181/00379727-82-20202.

Onyimonyi, A. E., Nwoga, C. C. and Ugwu, S. O. C. 2013. Semen quality of two breeds of toms subjected to different ejaculation frequencies. Research paper. 2(8). ISSN No. 2277 8160.

Savage, T. F. 2005. Guides to the recognition of parthenogenesis in incubated turkey eggs. Oregon State Univ. retrieved 2006.

Thatohatsi, M. B. M. 2009. Characterization and cryopreservation of semen of four South African Chicken Breeds. Magister Scientiae Agricultural Department of Animal, Wildlife and Grassland Science, University of the free state, Bloemfontein.
Walker, B. 2010. Scientific discover unknown lizard species at lunch uffet CNN. Retrieve 2010.

Yahaya, M. S., Umaru, M. A. and Aliyu, A. 2013. A preliminary study on semen collection, evaluation and insemination in Nigerian local turkeys (Meleagris gallopavo). Sokoto Journal of Veterinary Sciences, 11(2): 67-70.

Zaharaddeen, D., Burswat, I. S. R., Kall, D. J. U., Sir, S. M. and Bukar, T. M. 2005. Effect of frequency of ejaculation on semen characteristics in two breeds of turkey (Meleagris gullopavo) raised in tropical environment. International Journal of Poultry Science, 4(4): 217 221.

Received: $4^{\text {th }}$ July, 2019

Accepted: $18^{\text {th }}$ December, 2019 